\title{
Unsustainable Fiscal Policy: Implications for Monetary Policy
}

Renee Haltom and John A. Weinberg

$\mathrm{T}$ he debt of the United States government that is held by the public reached its highest point since World War II in 2011, at 67.7 percent of gross domestic product (GDP). ${ }^{1}$ Annual deficits surpassed 10 percent of GDP in 2009, the highest level since 1945, dipping to 8.7 percent of GDP in 2011. The early-to-mid 1980s was the only other point in the postwar period in which deficits exceeded 5 percent of GDP.

Recent numbers are high by historical comparison, but more important than the current size of the deficit and debt is the path they are likely to follow in the future. Federal debt held by the public was actually higher after World War II than it is today-109 percent of GDP in 1946, the highest level on record - but a key difference was that large deficits then were almost entirely associated with the temporary war effort. The same cannot be said today; several factors point to large demands on fiscal resources for most of the foreseeable future. Most

- The authors would like to thank Andreas Hornstein, Thomas A. Lubik, Aaron Steelman, and Alexander Wolman for discussions and detailed comments. The views expressed are those of the authors and not necessarily those of the Federal Reserve Bank of Richmond or the Federal Reserve System.

DOI: http://doi.org/10.21144/eq1010204

\footnotetext{
1 There are two common ways to measure the government's debt burden. Debt held by the public, used in this essay, reflects government borrowing from private financial markets. Total federal debt, the second common measure, comprises debt held by the public (private investors, including the Federal Reserve) and debt held by government accounts. The two measures have different implications. Debt held by the public can affect the current economy by crowding out private borrowing. In contrast, debt held by government accounts reflects internal transactions that are not traded in capital markets. However, that debt is nonetheless a legal liability of the federal government and a burden on taxpayers, which is why total debt is also used as a measure of the government's overall debt burden. We focus on debt held by the public because that is the measure for which long-term projections are readily available.
} 
prevalent is the aging population. The first baby boomers reached retirement age in 2011, and the fraction of the population aged 65 or older will surpass 20 percent by 2035, compared to 13 percent today. For the past 30 years, there have been roughly five working people in the United States for every person of retirement age; that number will drop to 2.8 after 2035. This "dependency ratio" is a rough approximation of the number of working individuals in the economy that support, through taxes and Social Security contributions, the people drawing age-related benefits from the government. The aging population will impose significant demands on federal resources through Social Security, Medicare, and Medicaid. These programs are written into law, which means their spending is not determined annually by the federal budgets created by the U.S. president and Congress, but instead can only be reduced through major overhauls to law. ${ }^{2}$

The nonpartisan Congressional Budget Office (CBO) projects the federal government's long-term budget outlook under two scenarios: a "baseline" scenario that holds current laws constant and an "alternative" scenario that incorporates the effects of laws the CBO deems likely to pass. (The budget outlooks under both scenarios are displayed in Figure 1.) The baseline scenario reflecting current laws presents the more optimistic view of the future path of fiscal policy. Tax revenues are projected to reach much higher levels than in recent history, while each category of spending except that on Social Security, health care entitlements, and interest payments on debt is projected to fall to its lowest level since World War II. Still, the increase in revenues and decline in other spending would be slightly more than offset by increased spending on Social Security, Medicaid, and Medicare as the population ages. Therefore, deficits would remain positive, causing debt levels to grow slowly over time. Under the baseline scenario, debt held by the public would rise to 84 percent of GDP by 2035, staying in that ballpark for the remaining decades of the forecast. (See Figure 2.)

The alternative scenario - the one the $\mathrm{CBO}$ considers more likelypresents a more alarming picture of the growth in federal debt. In

\footnotetext{
2 The aging population may not be the only source of coming strains on government budgets. Additional, though less certain, liabilities stem from the government's implicit support of other sectors of the economy. This is the support that market participants may assume the federal government will provide to certain markets in the event of trouble, including contingent support to the housing agencies Fannie Mae and Freddie Mac, as well as private pension funds. Whether the government ever will provide this implicit support is highly uncertain, but John Walter and Nadezhda Malysheva (2010) estimated that more than half the private financial sector-potentially $\$ 25$ trillion in liabilities, far greater than the size of the economy - was likely to enjoy some explicit or implicit federal backing at the end of 2009. Not included in their analysis were public sector pensions, which are underfunded by more than $\$ 3$ trillion, more than triple states' outstanding debts, according to the most pessimistic estimates.
} 


\section{Figure 1 Projected Budget Gaps (as a Percent of GDP)}

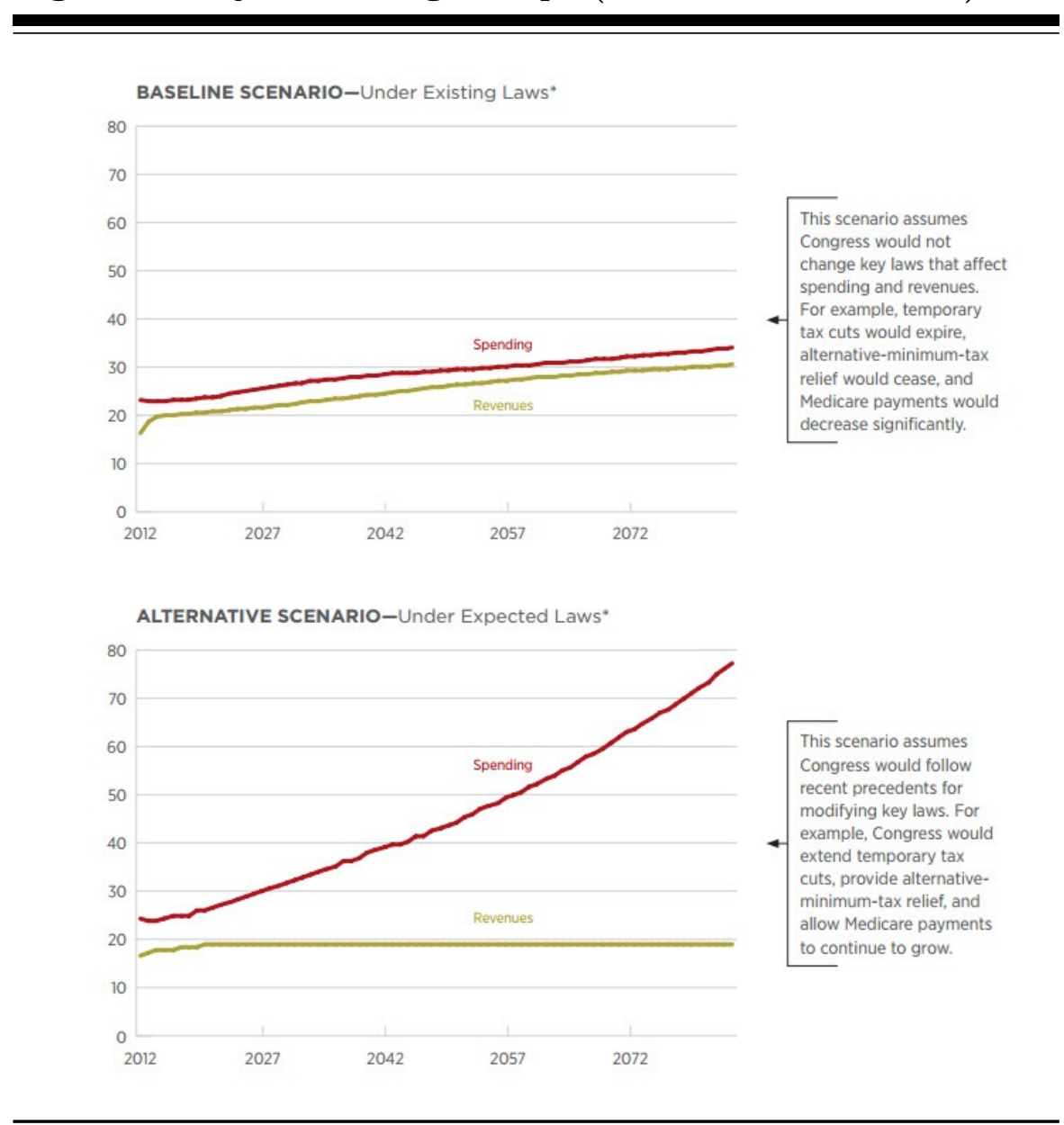

Source: Congressional Budget Office's 2011 Long-Term Budget Outlook.

Notes: The Congressional Budget Office produces two long-term budget projections: the "baseline" scenario, based on current laws, and the "alternative" scenario, based on laws expected to pass. *Projections begin with the 2012 budget.

that scenario, revenues do not rise much from where they are today, yet spending grows rapidly. This is because of law changes the CBO deems likely to take place, including an extension of the tax cuts that were enacted since 2001 and extended in 2010. The CBO also assumes that tax laws will be changed to keep tax revenues close to their long-run average of 18.4 percent of GDP, rather than rising to historically large levels as they do in the baseline scenario. In addition, 


\section{Figure 2 Federal Debt Held by the Public (as a Percent of GDP)}

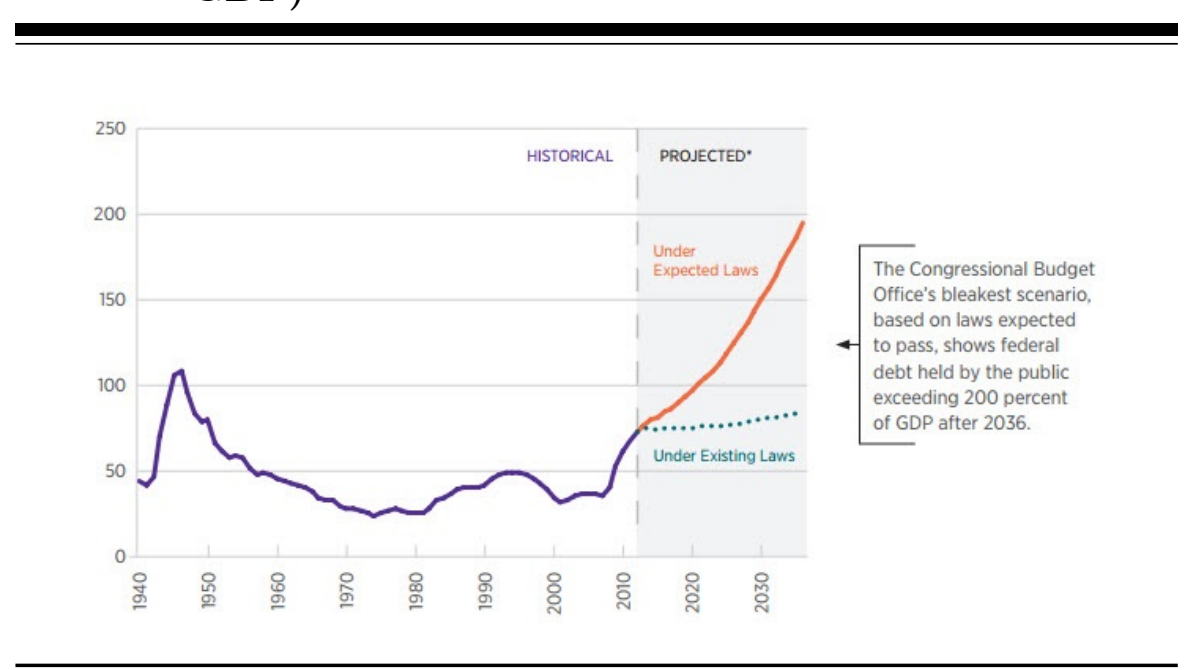

Source: Congressional Budget Office's 2011 Long-Term Budget Outlook.

Federal debt held by the public consists primarily of U.S. Treasury securities, including those held by the Federal Reserve. It does not include debt held in federal government accounts or securities issued by Fannie Mae or Freddie Mac. *Projections begin with the 2012 debt level.

Medicare payments are not assumed to decrease as current law dictates, health care spending under the major reform bill passed in 2010 is not assumed to decrease after 2021 as current law prescribes, and spending on non-entitlement programs is not assumed to fall as rapidly as in the baseline scenario. Under these conditions, federal debt held by the public would rise sharply after 2011, exceeding its historical record of 109 percent of GDP as early as 2023. It would surpass 200 percent of GDP - far more than double today's share of GDP — by the late 2030s.

The two scenarios represent optimistic and pessimistic alternatives from a range of possible outcomes. The exercise shows that the evolution of the federal government's fiscal position depends largely on policy decisions that have yet to be made. Given the demands on fiscal resources coming from the aging population under existing laws, achieving a path toward fiscal balance will involve very difficult tradeoffs for fiscal policymakers. 


\section{UNSUSTAINABLE FISCAL POLICY}

Economists use the word "unsustainable" to describe debt levels projected by the CBO's alternative scenario, a characterization reflecting the likelihood that financial markets would force a painful adjustment in fiscal policy before such debt levels could be reached. That notion is based on a simple framework called the government's intertemporal budget constraint. "Intertemporal" simply means "over time," while a budget constraint is a basic accounting identity that says an entity must pay for everything that it purchases. The government's intertemporal budget constraint says that the value of the government's outstanding debt must equal the present value of its expected future surplusesthat is, what financial markets believe surpluses will be, calculated in today's dollars.

The intertemporal budget constraint suggests that any time the real debt increases by even a small amount - a budget deficit is run in a single year - the expectation of future taxes or spending must adjust to put the equation in balance. However, the equation says only that surpluses must eventually rise; it provides no guidance on when that must occur. Historical experience doesn't provide a great deal more insight. For example, the U.S. government ran moderate deficits, averaging roughly 3 percent of GDP every year, from 1970 to 1997, with no obvious concern from financial market participants about the sources of future surpluses. That experience would imply that governments can sustain moderate deficits seemingly indefinitely.

That is less likely to be true when the imbalance between outstanding debt and future surpluses is very large. The larger the debt grows, the larger future surpluses - revenues in excess of spending - must be to satisfy the equation. However, there are limits to future surpluses. Spending cannot drop to zero; to the contrary, spending is expected to rise to historically high levels as a percent of GDP even under the CBO's most optimistic scenario, and tax revenues have an upper limit. As tax rates grow higher, they distort incentives to work and produce, and at very high rates would shrink the revenue collected by the government. There are likely to be political limits to tax revenues even before that point is reached, a reality reflected in the CBO's alternative scenario assumption that tax revenues will revert to their historical average of 18.4 percent of GDP within a decade. With debt levels predicted to grow much larger than GDP within two decades, it is clear that many years of higher taxes would be required to produce enough

surpluses to resolve the resulting imbalance. There is some level of debt that is high enough - although how high is difficult to predictthat generating the amount of future surpluses required would simply be infeasible. 
That point is what economists have called the "fiscal limit." At the fiscal limit, the government cannot borrow further, and the government's existing spending promises therefore cannot be funded. At least one of two events must occur at the fiscal limit: the government would reduce its debt levels by defaulting, or real debt levels would be reduced through actions taken by the central bank.

There are two main ways in which central banks can improve governments' fiscal positions. The first is through "seigniorage," the revenue that governments effectively receive when central banks create money. In the United States, it comes from the interest the Fed earns on the Treasury securities it purchases to expand the money supply. The Fed retains only the interest revenue that it requires to fund operations, and turns the rest over to the Treasury each fiscal year. ${ }^{3}$ The level of seigniorage remitted annually does not significantly affect debt: it amounts to slightly more than 1 percent of revenues in most years. ${ }^{4}$ The governments of most developed nations do not regularly rely on seigniorage as a funding strategy because overreliance on seignioragethat is, on money creation - will inevitably lead to rising inflation. Perhaps the most famous example of printing money to fund government operations is Germany in the early 1920s, when the price level doubled every two days. This action is sometimes called "monetizing" government debt: if the market grows unwilling to purchase government debt at low rates, the central bank can step in to purchase that debt directly from the government. Stanley Fischer, Ratna Sahay, and Carlos Vegh (2002) estimate how much government revenue can be created through seigniorage from a sample of 24 countries in the post-World War II period. Those nations created enough money to push annual inflation above 100 percent. During those episodes, seigniorage amounted to just 4 percent of GDP on average - not enough to cover their average deficits of just below 5 percent of GDP. By comparison, deficits under

\footnotetext{
${ }^{3}$ This revenue for the Treasury effectively is a tax on the public's holdings of noninterest-bearing money - the currency and bank reserves issued by the Fed-since the public would have otherwise earned interest from holding those treasuries.

${ }^{4}$ Since 2009, the Fed has produced a larger than average amount of seigniorage because the Fed has earned greater interest revenue due to the large expansion of the Fed's balance sheet to treat the financial crisis. From 2001 through 2008, the Fed turned an average of $\$ 26$ billion over to the Treasury each fiscal year, averaging 1.1 percent of gross fiscal receipts. From 2009 through 2011, the Fed turned an average of $\$ 67.9$ billion over to the Treasury each year, or roughly 2.7 percent of gross fiscal receipts. Data for the Fed's annual remissions to the Treasury can be found in the annual reports of the Federal Reserve Board of Governors, available on its website. Though the seigniorage revenue remitted to the Treasury has been larger in recent years due to the Fed's increased interest income, partially offsetting that increased income is the fact that the Fed, as of 2008, pays banks interest for the reserves they hold. The Federal Reserve System paid $\$ 3.8$ billion to banks in 2011 in interest on reserves and term deposits.
} 
the CBO's alternative scenario are projected to grow from a low of 5.6 percent of GDP in 2014 to more than 57 percent of GDP by 2085 .

Aside from seigniorage, a central bank can reduce the government's debt burden by creating inflation that was not anticipated by financial markets. Inflation allows all borrowers, the government included, to repay loans issued in nominal terms with cheaper dollars than the ones they borrowed. In the United States, inflation tends to be low and predictable from year to year. Inflation that is higher than expected, and therefore not priced into the contract interest rate, tends to produce only a small transfer of wealth from lenders to borrowers. (Indeed, this is one strong rationale behind the Fed's price stability objective for monetary policy.) However, roughly 90 percent of the federal government's debt is issued in nominal terms at prices that reflect the market's expectations for inflation over the life of the loan. A significant deviation from those expectations would produce a larger transfer of wealth from lenders to borrowers. Historically, some central banks - though never the Federal Reserve - have even produced inflation for the sole purpose of eroding the value of the government's debt.

Today, the central banks of most developed nations operate independently of fiscal policy considerations, and none that the authors are aware of produce inflation for the explicit purpose of reducing government debt levels. Between low, stable inflation and minimal seigniorage revenue, the Federal Reserve's policies generally have little direct impact on the government's debt burden. (See Box 1 for an overview of other ways in which fiscal and monetary policies interact.) This could change, however, if financial markets began to view hitting the fiscal limit as a possibility. That situation would inevitably invite monetary policymakers to intervene since inflation presents one possible source of revenue. (See the Appendix for a discussion of ways in which this pressure could arise in a crisis.)

In fact, economic research suggests that high debt levels ultimately could overwhelm a central bank's efforts to keep prices stable. The remainder of this essay will argue that these outcomes should be avoided in the United States by putting fiscal policy on a sustainable path.

\section{SOURCES OF FISCAL INFLATION}

Even without direct political pressures on the central bank to create inflation, unsustainable fiscal policy may be able to force that outcome. Inflation is commonly argued to be "always and everywhere a monetary phenomenon," a statement reflecting the monetarist notion that in the long run, inflation can be created only by the central bank's actions to increase the money supply. However, economists Thomas Sargent and 
Neil Wallace (1981) show that the central bank may not have control over inflation in times of fiscal crisis. This stems from the idea that the public has a limited demand, based on its private portfolio preferences, to hold government debt as a percent of GDP. Sargent and Wallace model a scenario in which the government has reached that limit on debt, yet continues to run budget deficits. If the government is to avoid default, the central bank has no choice but to produce inflation to reduce debt levels and satisfy the intertemporal budget constraint. In this scenario, monetary policymakers uncharacteristically focus on stabilizing debt, while inflation is determined by deficit policy. ${ }^{5}$

Does this scenario resemble the way monetary and fiscal policies are conducted in the United States? In the Sargent and Wallace framework, fiscal authorities "move first" by choosing levels of debt and surpluses, leaving monetary policymakers to make up for any imbalance. However, the central bank may be able to constrain the actions of fiscal authorities by making the first move; that is, by firmly establishing the expectation among both fiscal authorities and market participants that it will not step in to reduce debt levels with inflation. ${ }^{6}$ One could argue that this is the way monetary policy is conducted in the United States, such that the inflationary outcome that Sargent and Wallace describe need not be a concern. Since the early 1980s, American monetary policy has tended to adjust interest rates fairly predictably in response to the performance of inflation and unemployment.

As a result of this consistent stance in opposition to inflation, financial markets view the Fed's inflation objectives as highly credible, as evidenced by anchored inflation expectations. The same is true for the central banks of many other developed nations. Some central banks even face legally binding price stability mandates, such as the Bank of England, which must explain its failures to the Chancellor of the Exchequer, as well as the actions that are being taken to correct them. The credibility that these central banks have earned is bolstered by the operational independence most of them have been granted by their

\footnotetext{
${ }^{5}$ Sargent and Wallace label this outcome the "unpleasant monetarist arithmetic" of chronic fiscal deficits. Variations of this model are presented by Eric Leeper (1991), Christopher Sims (1994), John Cochrane (1999), and Michael Woodford (2001), among others.

${ }^{6}$ Eric Leeper (1991) describes this as an "active monetary policy/passive fiscal policy" framework. An active policy is one that chooses its objectives-surplus or deficit levels for fiscal policy, or money supply growth for monetary policy - as it sees fit, leaving the "passive" entity to stabilize debt. If monetary policy is "active," it generally follows a policy that adjusts interest rates in response to inflation. When fiscal policy is active, it pursues the spending and tax policies it desires without necessarily stabilizing debt. If it chooses large debt levels, it will ultimately determine inflation as a result of Sargent and Wallace's "unpleasant arithmetic."
} 
governments, which insulates monetary policy from pressure to set aside price stability to temporarily boost the economy.

In practice, however, a central bank's credibility cannot constrain fiscal policy in any meaningful sense: it cannot stop fiscal policymakers from running budget deficits that continually expand the debt. As a result, whether high debt levels would lead to inflation depends critically on whether the public believes fiscal authorities will balance the intertemporal budget constraint, or instead leave fiscal imbalances to be addressed by inflation. Unfortunately, neither theory nor experience provides a good rule of thumb for when those expectations might begin to change, potentially unleashing a fiscal crisis, though it is reasonable to expect that such a shift becomes more likely as projected debt levels grow ever larger. For example, Eric Leeper (2010) imagines a scenario in which the federal government is almost at its fiscal limit, but fiscal authorities still have some ability to adjust fiscal policy to stabilize debt levels. Being near the fiscal limit is enough to enable an equilibrium in which markets expect the central bank to accommodate the debt with inflation in the future. The public's expectation of higher inflation can push actual inflation higher before the central bank decides to create a single dollar. ${ }^{7}$

To emphasize the power of expectations in creating inflation, it is worth noting that a change in expectations also could bring an inflationary episode to a quick end. Sargent (1981) looked at the hyperinflations experienced by Austria, Hungary, Germany, and Poland after World War I. Each country financed massive government deficits and war reparations through sales of government debt to the central bank, resulting in hyperinflation. In each case, hyperinflation was brought to a sudden end through drastic regime changes in both fiscal and monetary policies: each nation established an independent central bank that was legally prohibited from extending credit to the government and established rules that limited fiscal policy to financing debt through private markets. In each case, the regime change credibly convinced market participants that the central bank would no longer finance fiscal policy.

The lesson from this literature is that when the public expects fiscal authorities to take action to satisfy the budget constraint while they still can, inflation need not rise. This is perhaps the situation in the United States today: debt projections under the CBO's more

\footnotetext{
${ }^{7}$ This effect presents an outcome similar to the "unpleasant monetarist arithmetic" - that chronic fiscal deficits can lead to inflation-except that here inflation can arise even without monetary accommodation provided by the central bank. Accordingly, this branch of literature is called "the fiscal theory of the price level." Several of the references provided in footnote five follow this line of thinking.
} 
likely scenario exceed historical records for most developed countries, yet markets appear perfectly willing to purchase government debt at low interest rates, indicating that inflation expectations remain low. Apparently markets believe fiscal imbalances will be resolved through fiscal policy rather than through inflation. However, as long as there is uncertainty over the feasibility of generating sufficient future surpluses, policymakers cannot be sure that market expectations will not shift unexpectedly and produce inflation. Leeper (2010) argues that a way to reduce that uncertainty would be to establish clear rules that govern fiscal policy in times of fiscal strain to avoid long-term imbalances, a topic discussed at the end of this essay. In the meantime, since uncertainty remains over how current fiscal imbalances would be resolved, it is useful to consider the options facing the central bank in an environment of fiscal crisis.

\section{ENCOURAGING SUSTAINABLE POLICY}

Credible monetary policy may help postpone the spike in inflation expectations that the above literature describes by convincing the public that the central bank will not quickly or easily agree to erode the debt through inflation. In many developing countries, central banks have a history of creating large amounts of inflation to help governments finance spending. For countries with that history, fiscal imbalances may more easily lead to a spike in inflation. Fortunately, the United States has no such history. The Fed can preserve its credibility by continuing to meet its price stability objectives, a task made more complicated in times of economic turbulence. In the past few years, weak economic conditions have greatly influenced the policies of the Fed and many other central banks, while inflation has perhaps been less of an immediate concern. It is useful to remember that the Fed's credibility helps make policies aimed at supporting real economic growth more effective. For example, markets remained confident in 2008 that the Fed would act to constrain any inflation pressures that emerged, even as the Fed added extraordinary liquidity to the banking system.

There are additional steps that can be taken to bolster the Fed's credibility. Elected leaders could reaffirm the central bank's independence to reassure markets that the Fed will not face political pressure to erode the debt through inflation, similar in spirit to the formal accord struck between the Fed and the Treasury Department in 1951. (See Appendix.) A formal target for inflation, like the one adopted by the Fed in early 2012, may strengthen the central bank's perceived commitment to avoiding inflation. 
However, these steps may not be sufficient. As research by Sargent and Wallace and others describes, fiscal policy that does not contain the debt may lead to inflation even if monetary policymakers have the best intentions. This is due to the incontrovertible nature of the government's intertemporal budget constraint. When the expected path for fiscal policy does not by itself achieve balance in the constraint over time, the price level is the only other factor that can adjust to provide it.

It is useful to consider how much inflation would be required to adequately reduce current debt levels. The opening paragraphs of this essay noted that the historical peak of the U.S. debt-to-GDP ratio was reached after World War II. Counting only the portion of that debt that could easily be bought and sold in public markets, George Hall and Sargent (2011) estimate that it took 30 years for debt to fall from 97.2 to 16.9 as a percent of GDP. They estimate that about 20 percent of that debt reduction came from inflation. (Annual inflation, measured by the Personal Consumption Expenditures Price Index, averaged 3.2 percent over that time period.) To consider how much inflation would be required today to address current debt imbalances, Michael Krause and Stéphane Moyen (2011) estimate that a moderate rise in inflation to 4 percent annually sustained for at least 10 years - in effect a permanent doubling of the Fed's inflation objective - would reduce the value of the additional debt that accrued during the 2008-09 financial crisis, not the total debt, by just 25 percent. If the rise in inflation lasted only two or three years, a 16 percentage point increase -from roughly 2 percent inflation today to 18 percent - would be required to reduce that additional debt by just 3 percent to 8 percent. Such inflation rates were not reached even in the worst days of the inflationary 1970s. The reason inflation has such a minimal impact on debt in Krause and Moyen's estimates is that while inflation erodes the value of existing nominal debt, it increases the financing costs for newly issued debt because investors must be compensated to be willing to hold bonds that will be subject to higher inflation. This effect would be greater for governments such as the United States that have a short average maturity of government debt and therefore need to reissue it often.

With these estimates in mind, it is worth recalling the CBO's projection that debt held by the public may triple as a percent of GDP within 25 years. The estimates cited above suggest that inflation is simply not a viable strategy for reducing such debt levels. In addition, it is important to remember that inflation is costly on many levels. Inflation high enough to significantly erode the debt would inflict considerable damage on the economy and would require costly policies for the Fed to regain its credibility after the fact. Inflation that was 
engineered specifically to erode debt would provide a significant source of fiscal revenue without approval via the democratic process, and so would raise questions about the role of the central bank as opposed to the roles of Congress and the executive branch in raising fiscal revenues.

Ultimately, the solution to high debt levels must come from fiscal authorities. Decades of monetary policy research suggests that rules and institutions can help ensure that central bankers take a longrun view of their policy objectives, even when doing so entails difficult or unpopular policy choices in the short term. Monetary policymakers have increasingly adopted transparent and consistent practices that make their policy rules credible and reduce uncertainty over their priorities.

The same rules-based institutions do not currently exist for fiscal policy. To a degree, this is a matter of necessity: the distributional nature of fiscal policy ought to be subject to the approval of the general public via the political process. However, it may be possible to create better rules for the more objective aspects of fiscal policy, a point argued by Leeper (2010). Just as Congress has agreed to set longrun objectives for the Fed while leaving day-to-day policy choices to independent monetary policymakers, fiscal policymakers could adopt objective long-run goals for fiscal policy - such as appropriate long-run targets for the ratio of debt to economic growth, guidelines for when unusual circumstances justify a large increase in debt, and how quickly fiscal imbalances should be resolved in that situation-while leaving the distributional details to the democratic process.

With that said, guaranteeing that policymakers will remain committed to those rules is difficult in practice.

The recent fiscal crisis in Europe provides telling proof. As a precondition to joining the European monetary union, 17 nations agreed to the Stability and Growth Pact, an agreement obligating each nation to maintain annual deficits of less than 3 percent of GDP and overall debt levels of less than 60 percent of GDP. Even the threat of sanctions for breaching this agreement was not enough to bind the fiscal policies of many European nations, including ones that have been the focus of the recent debt crisis and ones currently in relative fiscal health. If everyone knows that there are circumstances under which the rules will be violated - such as a demographic shift or an unprecedented financial crisis that calls upon national resources - then those rules will fail to anchor expectations. Though rules may be helpful, they may not be enough without some mechanism for enforcing them.

Despite the difficulties of establishing fiscal rules to reduce uncertainty over how fiscal imbalances would be resolved, there are encouraging examples from within the United States of fiscal policymakers 
adopting a longer-term perspective. Before the Constitution was created, the federal government had no power to levy taxes without unanimous approval from the states. After a period in which both federal and state debt became significantly devalued, the fiscal regime was changed in 1790 by creating new powers for federal taxation and, as a quid pro quo, nationalizing state debt. This policy established an unfortunate precedent for relieving local governments of their debt burdens. Nearly 50 years later, the states again had incurred heavy debts and defaulted after the recession of the late 1830s. Creditors again looked to the federal government, but Congress rejected proposals to take on state debt, arguing that states had entered into debt of their own accord to finance local projects. The decision was costly to the federal government. Its reputation suffered because international creditors did not distinguish between state and federal debt, yet the decision forced states to rewrite their treatment of debt in their constitutions. Many adopted the balanced-budget amendments they retain today. Sargent (2011) describes this episode as an example of how fiscal crises can lead to positive institutional changes.

Ultimately, the solution to current fiscal imbalances will require our elected authorities to make difficult decisions. The Fed's best contribution to this process is to maintain its commitment to monetary policy objectives, including low and stable inflation. For the time being, markets appear to believe that fiscal policymakers will put future debt, spending, and tax levels on a more sustainable path. If they are correct, our nation will not have to experience the significant economic challenges of a world in which those expectations have changed.

\section{APPENDIX}

The following sections appeared as sidebars in the original article.

\section{THE INTERACTION BETWEEN FISCAL POLICY AND MONETARY POLICY}

Several of the everyday interactions between fiscal policy and monetary policy do not have a large effect on their respective goals to support a strong economy.

The most direct interaction in the United States is that monetary policy is conducted in the secondary market for U.S. Treasury securities. The Fed buys treasuries to put money into the banking system 
when it wants to accommodate economic growth, and sells them to remove money and suppress inflation. The Fed does not exchange securities directly with the U.S. Treasury, but instead conducts transactions with private financial market participants, which avoids conflicts of interest that could otherwise arise from this relationship. The Fed also affects the government's borrowing costs when it raises interest rates in times of strong economic growth. Today the Fed's independence avoids pressure to make borrowing cheaper for the government, but this was not always the case.

More fundamentally, both fiscal policy and monetary policy affect the broader economy through the spending and investment decisions of households and businesses - though neither has a perfect ability to manage the economy in this way - and as a result their policies can affect each other's goals. (This, too, has led to political pressures throughout the Fed's history, as discussed in the sidebar.) So the Fed must consider the effects of current fiscal policy when it sets monetary policy to pursue its goals of price stability and healthy employment. For example, the Fed must consider how fiscal actions are likely to affect private demand based on how and when people expect those actions to be paid for by increased taxes or future expenditure reductions. Another possible effect of debt-financed fiscal stimulus - and another way in which fiscal and monetary policy interact - is that it could put upward pressure on interest rates in the economy as government borrowing rises.

Finally, as the main essay discusses, fiscal policy can have costly implications for monetary policy in times of fiscal crisis.

\section{COULD THE FED'S MONETARY POLICY INDEPENDENCE WITHSTAND A FISCAL CRISIS?}

On March 4, 1951, the Federal Reserve and the Treasury Department publicly agreed that the Fed would end its nine-year program in support of fiscal policy. Soon after the United States entered World War II, the Fed had committed to regularly purchasing enough Treasury debt to keep the government's financing costs low. The agreement to end that program became known as the Fed-Treasury accord, and it marked the end of an era of strong Treasury influence over monetary policy decisions, helping to usher in a new era of Fed independence. The accord asserted the Fed's authority to independently determine the size of the money supply to reach its congressionally established goals, which today include stable prices and healthy employment. This separation 
of authority has been essential to keeping the Fed accountable while shielding monetary policy from short-term political influence.

The 1951 accord has not completely insulated the Fed from political intervention, however. Pressures on the Fed often have been motivated by a short-term interest in economic stimulus, but the Fed also has experienced pressures to place greater weight on price stability, including recently. Since the 1980s, despite occasional pressures, appreciation has grown both inside and outside of central banks for monetary policy independence as the best way to achieve both objectives.

The main essay points to research suggesting that fiscal imbalances can lead to inflation. This could occur most directly through explicit pressure from elected leaders to create inflation, but it also could stem from the central bank's desire to soothe an economy suffering from fiscal crisis.

It is useful to consider the conditions that likely would arise in fiscal crisis. The federal government would face two extreme choices: defaulting on its debt or enacting some combination of painful spending cuts and tax increases. The prospect of the first option would wreak havoc in financial markets as investors become concerned about the growing risk associated with U.S. Treasury securities. This effect has been demonstrated by the unfolding sovereign debt crisis in Europe. In early 2010, markets began to demand higher yields to hold debt issued by European governments that sustained large projected debt levels. The debt of some nations was downgraded by credit rating agencies, damaging the financial position of the many

European banks that hold large amounts of sovereign debt because the banks were then forced to raise more capital. A similar effect would arise in a U.S. fiscal crisis since Treasury securities are widely held by financial institutions and play an important role in many private market transactions as well. The European Central Bank responded by purchasing sovereign debt and also accepting that debt as collateral in loan agreements to banks. (The ECB's purchases were "sterilized," meaning that an equal amount in liquidity was removed from the financial system so that the purchases would not add to the overall money supply.)

The second option facing governments, a combination of sudden tax increases and broad cuts to services, could cause economic weakness in the short run. Independent of the possible short-run effects of fiscal "austerity," rational households and businesses are likely to hold back spending in anticipation of fiscal retrenchments even before such decisions are announced, particularly if there is uncertainty over the specific forms those adjustments would take. Without knowing whether payroll taxes will be higher in five years, a planned government 
investment project will come to fruition, or employer health care costs will change abruptly, firms may delay a broad spectrum of spending, hiring, and investment decisions until those various sources of uncertainty have been resolved. In Europe, too, the uncertain resolution of fiscal imbalances has dampened spending and economic activity. Though monetary policy cannot resolve this type of uncertainty, it is clear that both default and extreme fiscal retrenchment may threaten the central bank's economic objectives.

That is why the dynamics of fiscal crisis can create difficult shortterm tradeoffs for the central bank: the economic pain associated with fiscal crisis versus the longer-term costs of central bank intervention to reduce debt levels - including the risk of inflation, damaged central bank credibility, and a precedent for rescuing the government from its debt. At the same time, even the most conservative central banker might feel compelled to intervene in hopes of limiting a panic before it could grow more severe, despite the known costs of doing so. (A related discussion is presented by Jeffrey Lacker, 2011.)

Averting fiscal crisis entails making people believe that difficult fiscal policy choices will be made before they are forced by financial markets. Thus, creating that expectation may require fiscal constraint before it seems strictly necessary. Yet because of the difficult and unpopular tradeoffs required to achieve fiscal balance, it may be tempting for elected officials to delay action in hopes that monetary policy will relieve imbalances.

Experience since the 1951 accord and the prospects for how a fiscal crisis could unfold make clear the conditional nature of monetary policy independence. Extreme conditions could stress both the consensus in support of independence and the central bank's ability to act independently. While formal agreements like the accord can make overt political intervention in monetary policy more difficult, such "rules" cannot ensure that the central bank would escape difficult choices in times of crisis.

\section{REFERENCES}

Cochrane, John H. 1999. "A Frictionless View of U.S. Inflation.” In NBER Macroeconomics Annual 1998, edited by Ben S. Bernanke and Julio J. Rotemberg. Cambridge, Mass.: MIT Press. 
Congressional Budget Office. 2011. "2011 Long-Term Budget Outlook."

Fischer, Stanley, Ratna Sahay, and Carlos A. Vegh. 2002. "Modern Hyper- and High Inflations." Journal of Economic Literature 40 (3): 837-80.

Hall, George J., and Thomas J. Sargent. 2011. "Interest Rate Risk and Other Determinants of Post-WWII US Government Debt/GDP Dynamics." American Economic Journal: Macroeconomics 3 (July): 192-214.

Krause, Michael U., and Stéphane Moyen. 2011. "Public Debt and Changing Inflation Targets." Deutsche Bundesbank (April 29).

Lacker, Jeffrey M. 2011. "Understanding the Interventionist Impulse of the Modern Central Bank." Speech to the CATO Institute 29th Annual Monetary Conference, Washington, D.C. (November 16).

Leeper, Eric M. 1991. "Equilibria Under 'Active' and 'Passive' Monetary and Fiscal Policies." Journal of Monetary Economics 27: $129-47$.

Leeper, Eric M. 2010. "Monetary Science, Fiscal Alchemy." Paper presented at the Kansas City Fed Economic Policy Symposium at Jackson Hole (August).

Malysheva, Nadezhda, and John R. Walter. 2010. "How Large Has the Federal Financial Safety Net Become?" Federal Reserve Bank of Richmond Economic Quarterly 96 (Third Quarter): 273-90.

Sargent, Thomas J. 1981. "The Ends of Four Big Inflations." Federal Reserve Bank of Minneapolis Working Paper No. 158 (May).

Sargent, Thomas J. 2011. "United States Then, Europe Now." Nobel Prize Lecture (December 8).

Sargent, Thomas J., and Neil Wallace. 1981. "Some Unpleasant Monetarist Arithmetic." Federal Reserve Bank of Minneapolis Quarterly Review 5 (Fall).

Sims, Christopher A. 1994. "A Simple Model for Study of the Determination of the Price Level and the Interaction of Monetary and Fiscal Policy." Economic Theory 4 (3): 381-399.

Woodford, Michael. January 2001. "Fiscal Requirements for Price Stability." NBER Working Paper No. 8072. 